\title{
The effect of long-term dehydration and subsequent rehydration on markers of inflammation, oxidative stress and apoptosis in the camel kidney
}

Mahmoud A. Ali ${ }^{1}$, Hassan Abu Damir ${ }^{1}$, Osman M. Ali ${ }^{2}$, Naheed Amir ${ }^{1}$, Saeed Tariq ${ }^{3}$, Michael P. Greenwood ${ }^{4}$, Panjiao Lin ${ }^{4}$, Benjamin Gillard ${ }^{4}$, David Murphy ${ }^{4 *}$ and Abdu Adem ${ }^{1,5^{*}}$ (B)

\begin{abstract}
Background: Dehydration has deleterious effects in many species, but camels tolerate long periods of water deprivation without serious health compromise. The kidney plays crucial role in water conservation, however, some reports point to elevated kidney function tests in dehydrated camels. In this work, we investigated the effects of dehydration and rehydration on kidney cortex and medulla with respect to pro-inflammatory markers, oxidative stress and apoptosis along with corresponding gene expression.

Results: The cytokines IL-1 $\beta$ and IL-18 levels were significantly elevated in the kidney cortex of dehydrated camel, possibly expressed by tubular epithelium, podocytes and/or mesangial cells. Elevation of IL-18 persisted after rehydration. Dehydration induced oxidative stress in kidney cortex evident by significant increases in MDA and GSH, but significant decreases in SOD and CAT. In the medulla, CAT decreased significantly, but MDA, GSH and SOD levels were not affected. Rehydration abolished the oxidative stress. In parallel with the increased levels of MDA, we observed increased levels of PTGS1 mRNA, in MDA synthesis pathway. GCLC mRNA expression level, involved in GSH synthesis, was upregulated in kidney cortex by rehydration. However, both SOD1 and SOD3 mRNA levels dropped, in parallel with SOD activity, in the cortex by dehydration. There were significant increases in caspases 3 and 9, p53 and PARP1, indicating apoptosis was triggered by intrinsic pathway. Expression of BCL2/1 mRNA levels, encoding for $\mathrm{BCL}-\mathrm{xL}$, was down regulated by dehydration in cortex. CASP3 expression level increased significantly in medulla by dehydration and continued after rehydration whereas TP53 expression increased in cortex by rehydration. Changes in caspase 8 and TNF-a were negligible to instigate extrinsic apoptotic trail. Generally, apoptotic markers were extremely variable after rehydration indicating that animals did not fully recover within three days.

\footnotetext{
* Correspondence: abdu.adem@uaeu.ac.ae; d.murphy@bristol.ac.uk;

abdu.adem@uaeu.ac.ae; d.murphy@bristol.ac.uk

${ }^{4}$ Molecular Neuroendocrinology Research Group, Bristol Medical School,

Translational Health Sciences, University of Bristol, Dorothy Hodgkin Building, Bristol BS13NY, UK

'Department of Pharmacology, CollegeofMedicine\&HealthSciences, United Arab Emirates University, Al- Ain, United Arab Emirates

Full list of author information is available at the end of the article
}

C C The Author(s). 2020 Open Access This article is licensed under a Creative Commons Attribution 4.0 International License, which permits use, sharing, adaptation, distribution and reproduction in any medium or format, as long as you give appropriate credit to the original author(s) and the source, provide a link to the Creative Commons licence, and indicate if changes were made. The images or other third party material in this article are included in the article's Creative Commons licence, unless indicated otherwise in a credit line to the material. If material is not included in the article's Creative Commons licence and your intended use is not permitted by statutory regulation or exceeds the permitted use, you will need to obtain permission directly from the copyright holder. To view a copy of this licence, visit http://creativecommons.org/licenses/by/4.0/ The Creative Commons Public Domain Dedication waiver (http://creativecommons.org/publicdomain/zero/1.0/) applies to the data made available in this article, unless otherwise stated in a credit line to the data. 
(Continued from previous page)

Conclusions: Dehydration causes oxidative stress in kidney cortex and apoptosis in cortex and medulla. Kidney cortex and medulla were not homogeneous in all parameters investigated indicating different response to dehydration/rehydration. Some changes in tested parameters directly correlate with alteration in steady-state mRNA levels.

Keywords: Dromedary camels, Dehydration/rehydration, Kidney cortex/medulla, Gene expression, Oxidative stress and apoptosis, Pro-inflammatory markers

\section{Background}

The nephrons, located mostly in kidney cortex, are involved in the ultrafiltration of arterial blood, reabsorption of water, electrolytes and smaller molecules, whereas the medullary components of kidney, with the exception of the Henle loops and collecting ducts, are principally engaged in urine excretion. A number of hormones, peptides, receptors, aquaporins and solute carrier proteins work in harmony within the kidney tubules to maintain water and electrolyte balance [36, 28, 35]. The camel kidney, unlike human, horse and cattle, is beanshaped with a smooth surface and prominent medulla compared to cortex, with a volume ratio of 4:1 [1]. The dromedary camel nephron is similar to that of other species in terms of physiology, histology, morphometry and electron microscopy,however, it is peculiarly adapted to achieve the increased water reabsorption and urine concentration necessary for life in the arid desert environment $[47,55]$.

However, it is worth noting that small vesicular membrane-bound bodies have been reported in the dromedary camel kidney, which may be engaged in water and solute regulation $[8,9,19]$. Long-term dehydration can cause oxidative stress with increased reactive oxygen species (ROS), pro-inflammatory interleukins such as Interleukin $1 \beta$ (IL-1 $\beta$ ), Interleukin 6 (IL-6), Interleukin 18 (IL-18) and Tumor Necrosis Factor $\alpha$ (TNF- $\alpha$ ) and apoptotic markers [5]. Acute-injury of the kidney can result in DNA damage (with failure to repair), crowding of endoplasmic reticulum (ER) with an unfolded protein response (UPR), increased reactive oxygen species (ROS) and increased cellular apoptosis, amongst other effects $[41,46]$. Recurrent acute or chronic dehydration has also been implicated in insidious kidney injury in human and laboratory animals, which ultimately advances into chronic renal disease [12, 26]. The recently emerged disease, Mesoamerican nephropathy, diagnosed in sugar-cane farmers in Central America, exemplifies this $[44,56]$. On the other hand, desert animals display less severe responses to acute or chronic dehydrations [34, [33]. Although these animals undergo cellular stress, kidney apoptosis and tissue damage, consequences are less pronounced, which has been attributed to an acquired adaptive response to the harsh arid environment $[13,31]$. For example, desert mice subjected to acute dehydration displayed decreased kidney matrix-turnover and limited apoptosis with normal creatinine and other kidney markers,however, there was more expression of genes encoding for aquaporin and solute carrier proteins [34,33]. Long-term dehydration in the arid environment with its hot humid weather is very challenging to the dromedary camel [49] and [22]. Although, the camel kidney, like other desert mammals, is very efficient in water and electrolyte regulation [37], some reports point to high elevation in some kidney function tests, such as blood urea nitrogen, creatinine, sodium, osmolality and other relevant hormonal and peptides parameters $[4,2]$. It is worth mentioning that oxidative stress, histopathological changes and apoptotic markers were studied in our recent publication on the stomach of dehydrated camels [6]. However, our current knowledge of the effects of dehydration and rehydration on the camel kidney is limited. It is not known whether dehydration causes acute or chronic, temporary or permanent, effects on the camel kidney, or whether the kidney is refractory to stress, resuming full functionality immediately after rehydration with no further consequences.

The aim of this work was to investigate the effects of long-term dehydration and rehydration on pro- inflammatory cytokine markers, oxidative stress biomarkers and apoptosis markers in both cortex and medulla of the camel kidney. The expression of genes encoding for proteins and enzymes involved in these processes was also investigated.

\section{Results \\ Body weight}

There was no significant difference between all groups at the start of the experiment [30]. The body weights (mean \pm SEM) of the control group did not change significantly during the experimental period from (356.8 \pm 10.3 to $364.1 \pm 15 \mathrm{~kg}$ ). The body weights of the dehydrated group decreased significantly at the end of the dehydration period $(251.8 \pm 10.1$ vs $364.1 \pm 15 \mathrm{~kg})$ constituting $31 \%$ weight loss. Two hours after rehydration the body weights of the rehydrated camels increased by $17 \%$ $(251.8 \pm 10.3$ vs $294.5 \pm 13 \mathrm{~kg})$ compared to the dehydrated body weight. 


\section{Measurement of pro-inflammatory markers}

ELISA was used to measure steady state levels of proinflammatory interleukin markers (IL-1 $\beta$, IL-6, IL-18) in control, dehydrated and rehydrated camel kidney cortex and medulla Table 1. IL-1 $\beta$ in the dehydrated camel cortex displayed significantly higher values compared to rehydrated $(p<0.05)$ and control $(p<0.05)$ camels, whilst there was no significant difference between the rehydrated and control. No significant changes were apparent in kidney medulla. IL-6 levels did not change significantly comparing dehydrated, rehydrated and control groups in both cortex and medulla. IL-18 levels showed significant differences between dehydrated and control groups in the cortex. Moreover, the IL-18 levels in the cortex increased significantly after rehydration compared to the controls and dehydrated. However, the levels of IL-18 decreased significantly in the medulla of the dehydrated camels compared to the controls Table 1. At the steady-state mRNA level, qPCR revealed that IL-1 $\beta$ mRNA in the kidney medulla of rehydrated camels showed significantly higher expression level compared to control camels whereas no significant between the dehydrated and control values was observed Fig. 1. IL-6 values displayed no significant difference among the control and experimental groups in cortex and medulla. The mRNA expression level of IL-18 in the kidney cortex of dehydrated camel was significantly lower than the control values. Additionally, the IL-18 expression levels in the medulla increased significantly after dehydration and maintained until rehydration compared to the controls Fig. 1.

\section{Measurement of oxidative stress biomarkers}

Oxidative stress biomarkers Malondialdehyde (MDA), Total Glutathione (GSH), Superoxide dismutase (SOD), and Catalase (CAT) were quantified Table 2. The concentration of MDA in the camel kidney cortex was significantly higher in dehydrated camels compared to rehydrated and control camels but no significant difference between the rehydrated and control groups was observed. The kidney medulla displayed no significant differences in MDA between the three groups. GSH level showed a significant increase in the kidney cortex of dehydrated camels compared to rehydrated and control groups, which were comparable.

The activity of SOD is significantly decreased in the cortex of dehydrated camels compared to the rehydrated and control groups, which were not statistically different. The GSH concentration and SOD activity in the medulla of the three groups revealed no significant difference. CAT activity was significantly lower in the cortex $(\mathrm{p}<$ $0.001)$ and medulla $(\mathrm{p}<0.05)$ of dehydrated compared to the rehydrated and control groups. However, CAT values in rehydrated and control camels' cortices as well as medullae exhibited no significant difference Table 2 . Steady-state mRNA expression levels of genes encoding oxidative stress biomarkers (CAT and SOD1-3) and genes involved in the metabolisms of other oxidative stress markers (MDA and GSH) were quantified by qPCR Figs 2, 3, 4 and 5. The expression of steady state mRNAs that encode enzymes responsible for MDA synthesis (the TBXAS1,PTGS1 and PTGS2 genes) are presented in Fig. 2. No significant differences were observed for TBXAS1 among the control and experimental values in both cortex and medulla. For PTGS1, the expression level in cortex increased significantly during dehydration in comparison with the controls. Moreover, the PTGS2 mRNA expression level was significantly higher in the kidney cortex of rehydrated camels than the control camels.

However, in the kidney medulla, the expression level of PTGS2 showed significant increase during dehydration ACSS2 expression level significantly increased after being subjected to rehydration in the kidney cortex. The expression of GPI significantly increased during dehydration in cortex and during rehydration in medulla compared to the control groups Fig. 3. We observed different patterns for the expression of two genes involved in GSH synthesis Fig. 4. GCLC transcript levels displayed a significant up-regulation in kidney cortex during rehydration in comparison with the control groups. GSS mRNA expression levels showed no significant difference between the three groups in both cortex and medulla Fig. 4.

Table 1 Pro-inflammatory markers (IL-1 $\beta, I L-18$ and IL-6) in renal cortex and medulla of Control Dehydrated and Rehydrated camels (mean \pm SEM)

\begin{tabular}{lllll}
\hline Parameter & Tissue type & Control & Dehydrated & Rehydrated \\
\hline IL-1 $\beta$ pg/mg tissue & Cortex & $20.7 \pm 1.2$ & $23.8 \pm 0.6^{*}$ & $20.5 \pm 1.5 \dagger$ \\
& Medulla & $18.9 \pm 1.3$ & $18.5 \pm 0.8$ & $21.4 \pm 1.5$ \\
IL-6 pg/mg tissue & Cortex & $15.1 \pm 1.1$ & $16.5 \pm 1.4$ & $18.7 \pm 2.3$ \\
& Medulla & $7.7 \pm 1.0$ & $6.2 \pm 0.3$ & $8.8 \pm 2.5$ \\
IL-18 pg/mg tissue & Cortex Medulla & $8.17 \pm 0.26$ & $12.19 \pm 0.28^{* * *}$ & $15.41 \pm 0.55^{* * *+十}$ \\
& & $19.54 \pm 1.71$ & $15.03 \pm 0.90^{*}$ & $15.54 \pm 1.18$ \\
\hline
\end{tabular}

Significant difference from Control group is denoted by ${ }^{*} p<0.05,{ }^{* * *} p<0.001$ and from Dehydrated group by ${ }^{\dagger} p<0.05,{ }^{+\dagger} p<0.01$ 


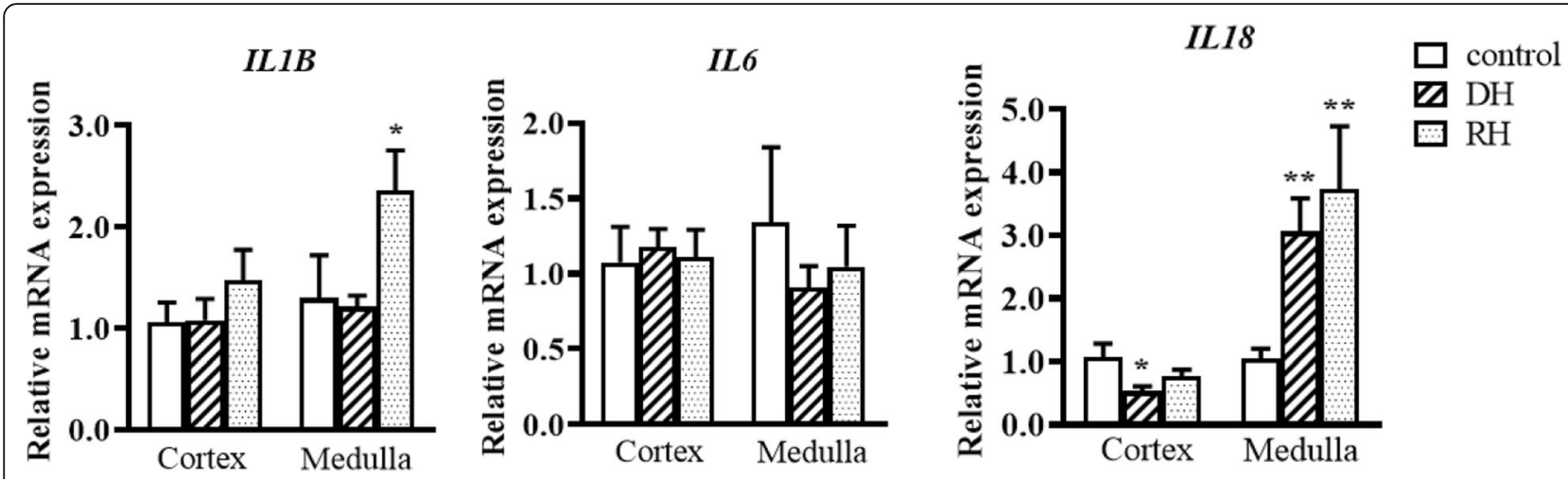

Fig. 1 Relative mRNA expression of pro-inflammatory markers in kidney cortex and medulla of Control, Dehydrated (DH) and Rehydrated (RH) Camels (mean \pm SEM). qPCR was performed to examine mRNA expression of IL-1 $\beta$, IL-6 and IL-18. Significant difference from Control group denoted by $p<0.05: *, p<0.01: * *$

In terms of the expression level of the oxidative stress markers, Fig. 5 illustrates that although no significant differences were observed for the expression levels of CAT and SOD2 mRNAs in both cortex and medulla between the three groups, SOD1 and SOD3 transcript expression levels in the kidney cortex during the dehydration stage were down-regulated significantly when compared with the control camels. Compared with the dehydrated group, the expression level of SOD 1 mRNAs in the cortex of the rehydrated group was significantly increased to attain the control level Fig. 5.

\section{Measurement of apoptotic markers}

ELISA quantification of steady-state levels of apoptotic protein markers; Caspase 3 (CASP3), Caspase8 (CASP8), Caspase 9 (CASP9), Tumor protein 53 (p53), B-cell lymphoma-extralarge (Bcl-xL), Poly ADP-ribose Polymerase (PARP1) in camel kidney cortex and medulla of control, dehydrated and rehydrated camel is presented in Fig. 6. Caspase 3, p53 and Bcl-xL are more expressed in cortex,PARP1 is more expressed in medulla, while caspases 8 and 9 are equally expressed in cortex and medulla. Caspases $(3,8,9)$, p53 and PARP1 significantly increased, whilst $\mathrm{BCL}-\mathrm{xL}$ significantly decreased in response to dehydration in both cortex and medulla.
During the rehydration period, the levels of caspase 3 and p53 dropped in cortex to reach control values, whilst the medullary values continued increasing only in the caspase 3. Caspase 9 and PARP1 continued increasing following rehydration in cortex, whilst in medulla, only PARP1 dropped significantly $(p<0.001)$. Bcl-xL continued significant increase $(p<0.05)$ in caspase 8 as a result of dehydration in both cortex and medulla, and values decreased to control values or significantly below in medulla and cortex respectively following rehydration Fig. 6 .

The steady-state expression levels of mRNAs encoding apoptotic markers (CASP3, CASP8, CASP9, TP53, $B C L 2 L 1$ [encoding $\mathrm{Bcl}-\mathrm{xL}$ ] and PARP1) are presented in Fig. 7. The expression of CASP8, CASP9 and PARP1 were not significantly different between the three groups in both cortex and medulla. For CASP3, its expression dropping in cortex $(p<0.01)$ of rehydrated camels but increased in medulla to reach control levels. Caspase 8 values were very low in kidney compared to organs such as abomasum (results not shown). However, there is slight but significant increase $(p<0.05)$ in caspase 8 as a result of dehydration in both cortex and medulla, and values decreased to control values or significantly below in medulla and cortex respectively following rehydration Fig. 6.

Table 2 Oxidative Stress Biomarkers in kidney Cortex and Medulla of Control, Dehydrated and Rehydrated camels (mean \pm SEM)

\begin{tabular}{lllll}
\hline Parameter & Tissue type & Control & Dehydrated & Rehydrated \\
\hline MDA $\mu \mathrm{M}$ & Cortex Medulla & $3.28 \pm 0.49$ & $5.03 \pm 0.47^{*}$ & $3.71 \pm 0.33+$ \\
& & $1.95 \pm 0.54$ & $2.20 \pm 0.40$ & $2.27 \pm 0.19$ \\
GSH $(\mu \mathrm{M})$ & Cortex & $4.96 \pm 0.34$ & $6.79 \pm 0.35^{* *}$ & $5.15 \pm 0.29+$ \\
& Medulla & $5.88 \pm 0.33$ & $5.87 \pm 0.36$ & $6.04 \pm 0.96$ \\
SOD U/mg & Cortex Medulla & $572.70 \pm 43.37$ & $398.47 \pm 55.01^{*}$ & $605.48 \pm 29.73 \dagger$ \\
& & $356.04 \pm 46.01$ & $377.78 \pm 26.14$ & $288.42 \pm 72.32$ \\
CAT nmol/min/mg & Cortex & $104.78 \pm 6.47$ & $56.93 \pm 6.86^{* * *}$ & $100.83 \pm 4.44 \dagger$ \\
& Medulla & $125.66 \pm 13.49$ & $77.75 \pm 13.34^{*}$ & $123.31 \pm 10.51 \dagger$ \\
\hline
\end{tabular}

Significant difference from control group is denoted by ${ }^{*} p<0.05,{ }^{* *} p<0.01,{ }^{* * *} p<0.001$ and from Dehydrated group by ${ }^{\dagger} p<0.05$. 


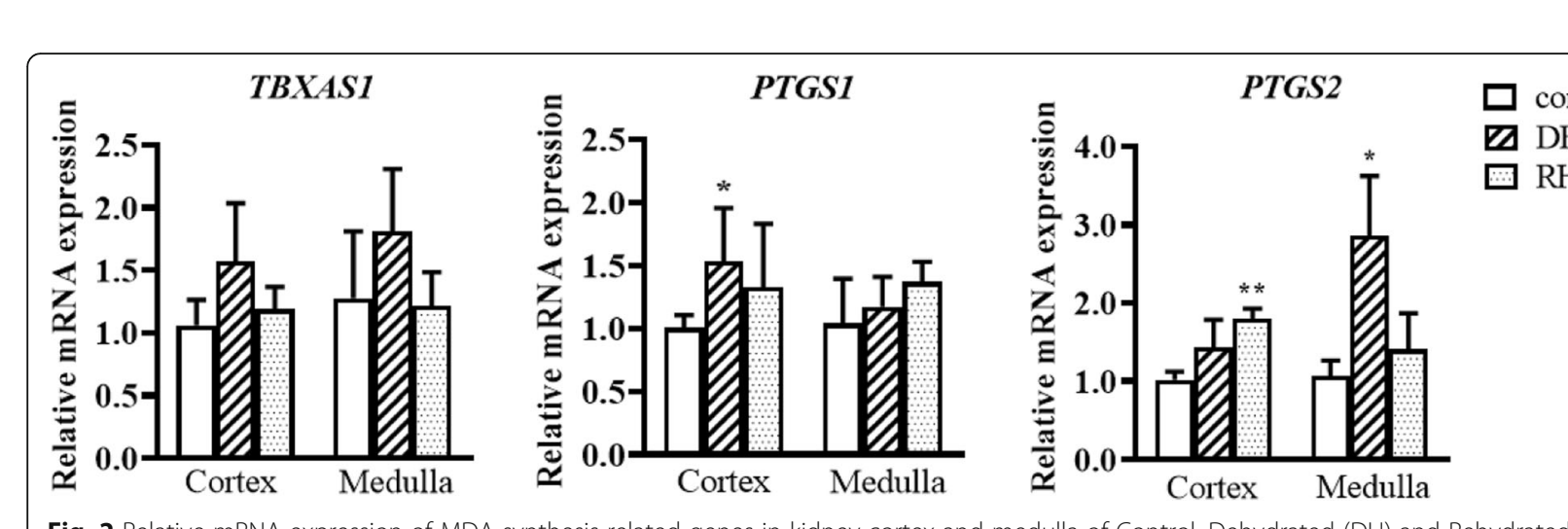

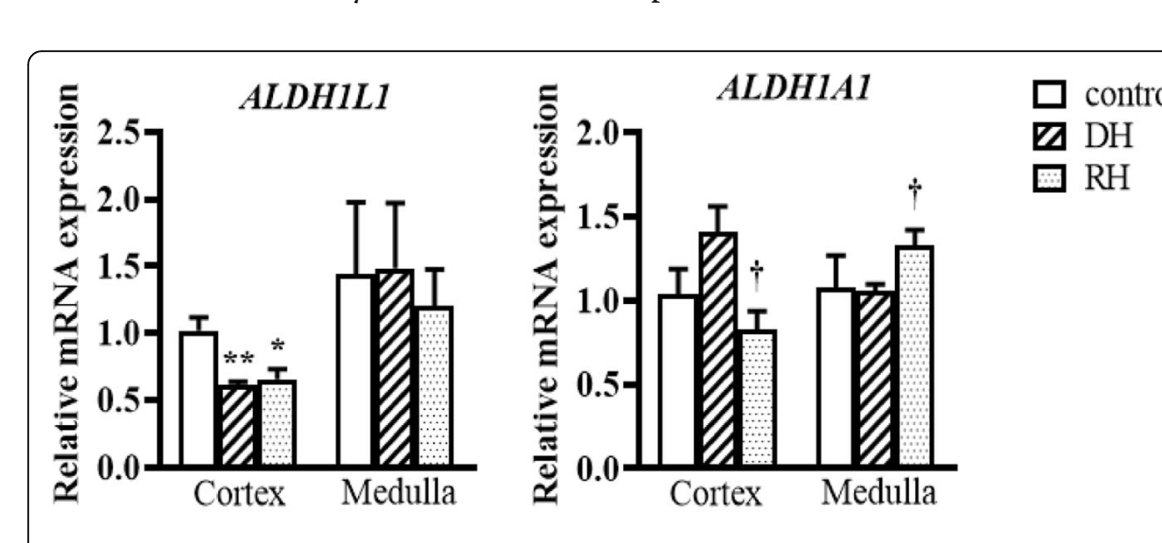

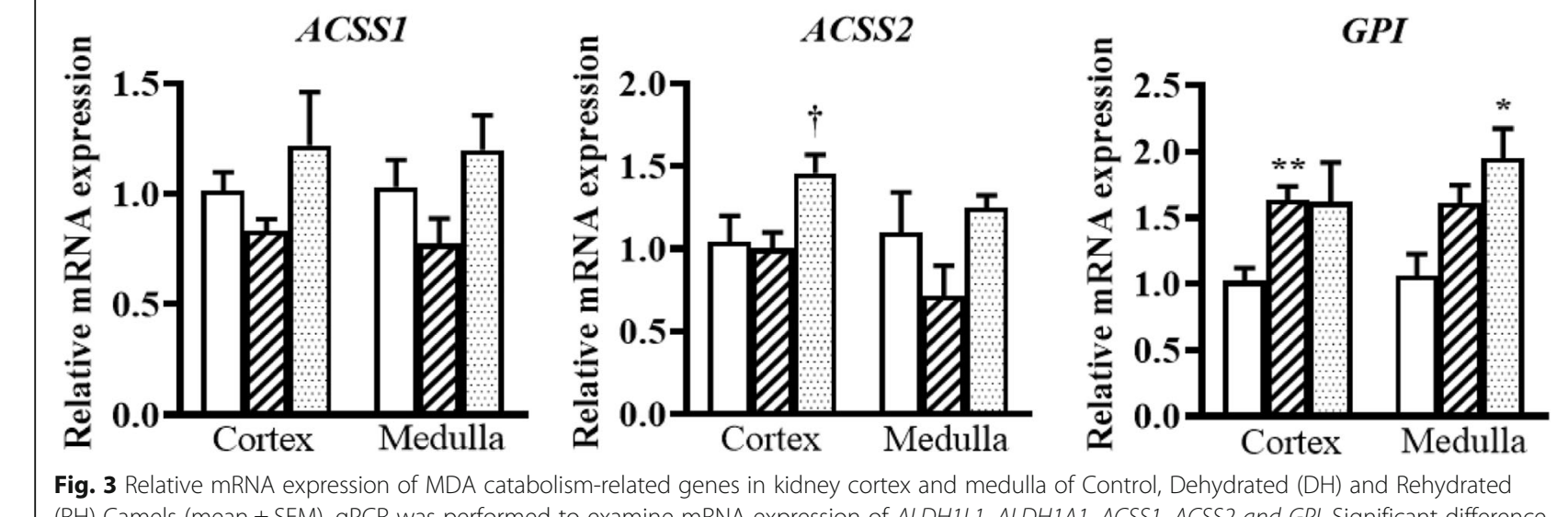




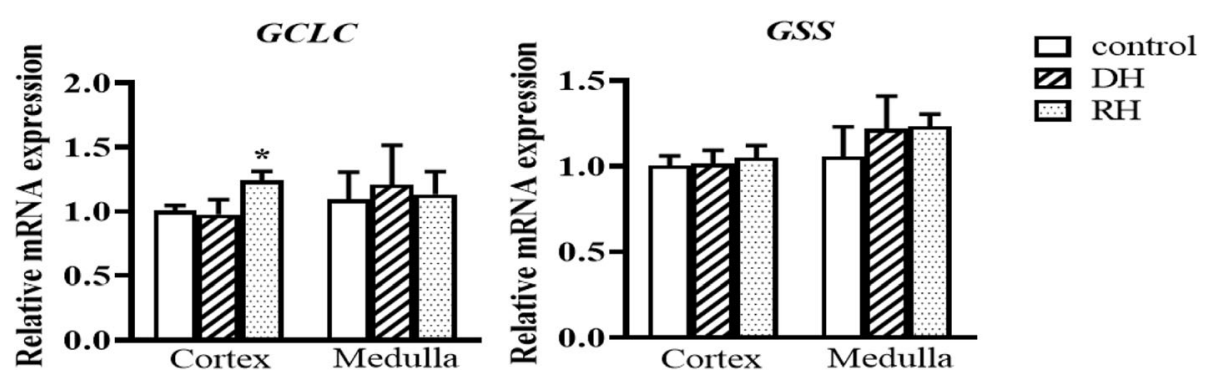

Fig. 4 Relative mRNA expression of GSH synthesis-related genes in kidney cortex and medulla of Control, Dehydrated (DH) and Rehydrated (RH) Camels (mean \pm SEM). qPCR was performed to examine mRNA expression of GCLC and GSS. Significant difference from Control group denoted by $p<0.05: *$

apoptosis accompanied changes in the levels of neuropeptide hormones, prostaglandin $\mathrm{E} 2$ and $\mathrm{H}^{+} / \mathrm{K}^{+}$ATPase to modulate the body activities towards water economy [6]. Generally, the kidneys of desert animals such as desert rodents displayed less severe inflammatory, oxidative and apoptotic responses to dehydration [35] compared to non-desert species where long-term dehydration or intermittent dehydration can cause severe kidney damage. The camel, being adapted to the harsh arid environment, can live without water for long periods similar to other desert species [13]. Therefore, it is interesting to investigate the extent of inflammation, oxidative stress and apoptosis when the camel kidney is subjected to long-term dehydration and subsequent rehydration and if these processes are directly correlated to alteration in steady-state m-RNA and if they have any effects on renal function. In this report, we presented new data pertinent to effects of dehydration/rehydration on kidney cortex and medulla. IL-18 and IL-1 $\beta$ are pro-inflammatory cytokines primarily produced by activated macrophages $[23,58]$ and both overlap in many functions but differ in signaling pathways with IL-1 $\beta$ being highly involved in pyrexia [27]. IL-18 is also expressed in many other cells, including the renal tubular epithelium, podocytes and mesangial cells [51, 57], and is considered an acute marker of tubular necrosis [42, 43]. IL-18 and IL-12
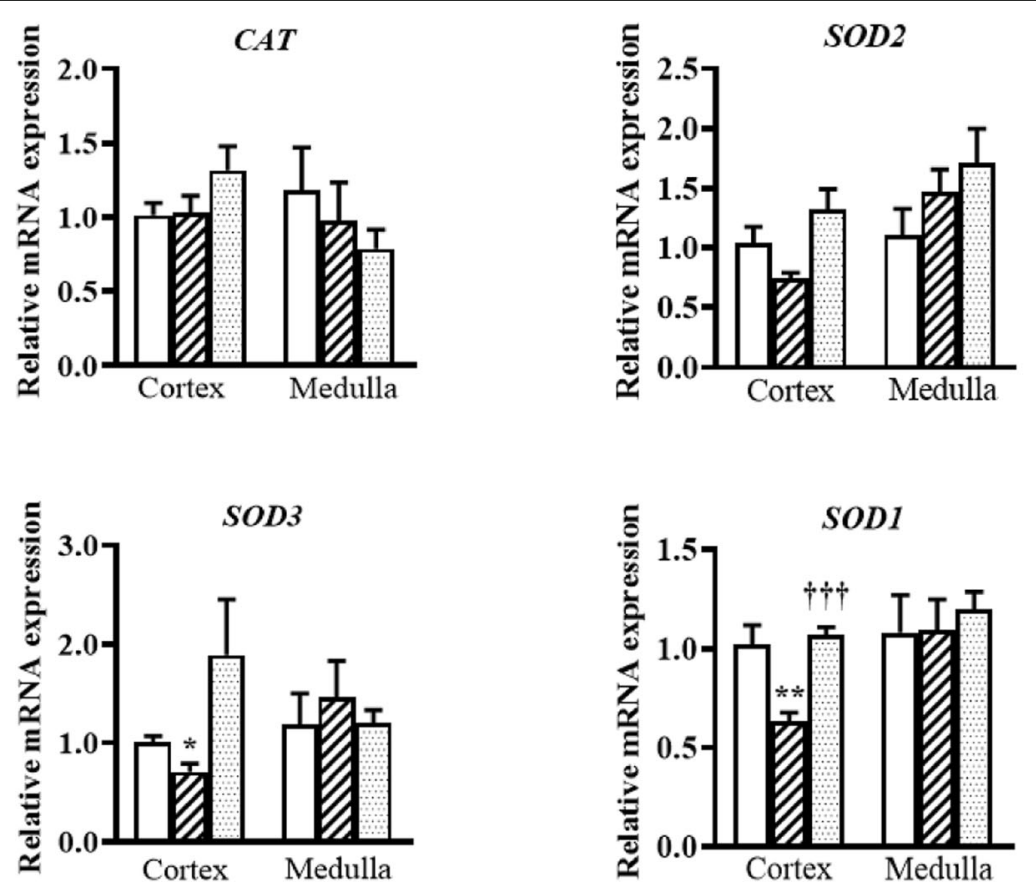

Fig. 5 Relative mRNA expression of oxidative stress markers in kidney cortex and medulla of Control, Dehydrated (DH) and Rehydrated (RH) Camels (mean \pm SEM). QPCR was performed to examine mRNA expression of CAT, SOD1, SOD2 and SOD3. Significant difference from Control group denoted by $p<0.05:{ }^{*}, p<0.01$ : ** and from Dehydrated group by $p<0.001:$ ††† 


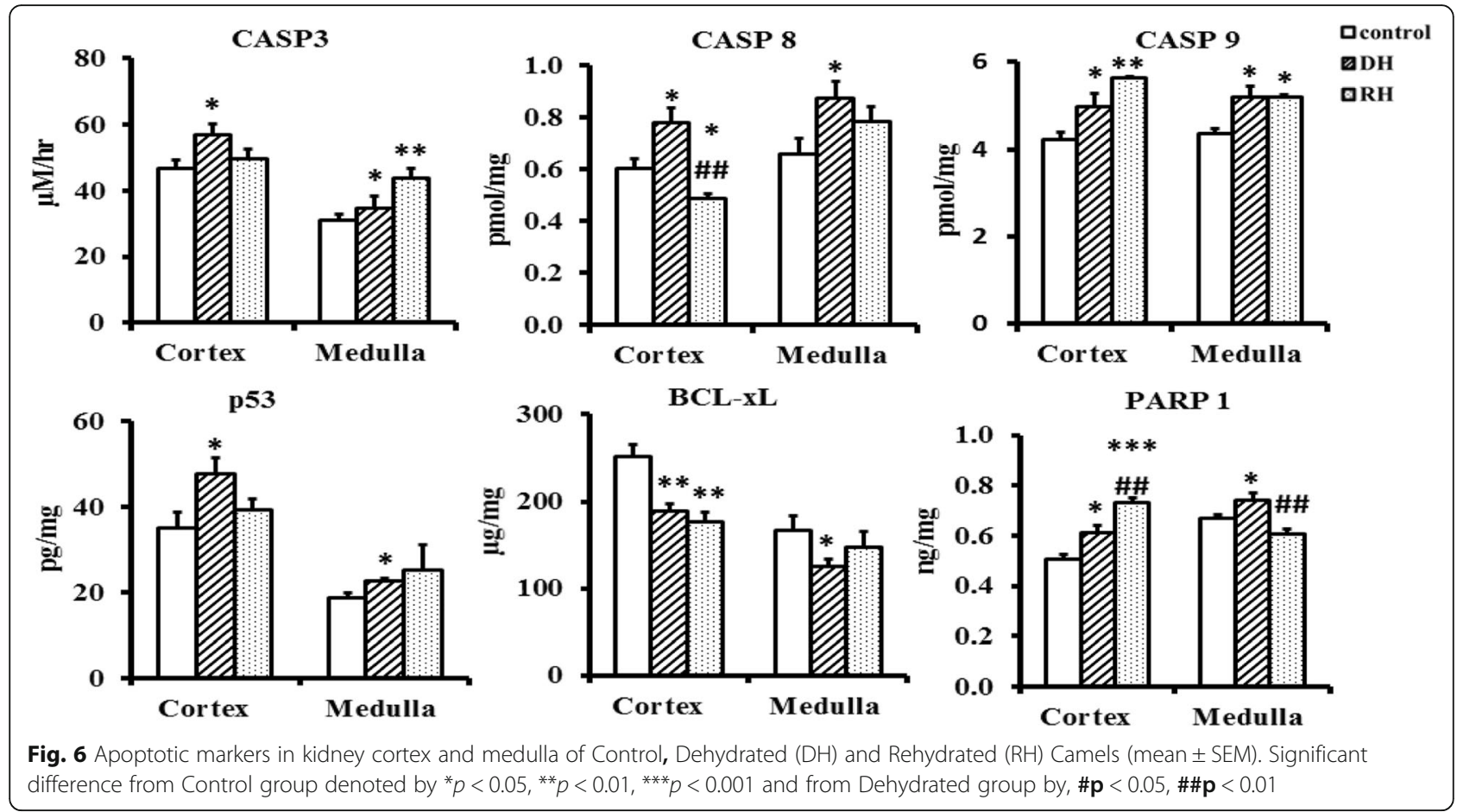

synergistically stimulate the production of interferon gamma (IFNY) by $\mathrm{T}$ lymphocytes and NK cells altering the transcription of more than 30 genes to elicit a number of inflammatory and autoimmune diseases [34, 53]. The increased IL-18 values seen in kidney cortex of dehydrated and rehydrated camels might have played crucial roles in gene expression and lesions particularly seen in podocytes, mesangial cells, capillaries, proximal and distal convoluted tubules, whereas the medullary collecting ducts and parenchyma seemed to be refractory.

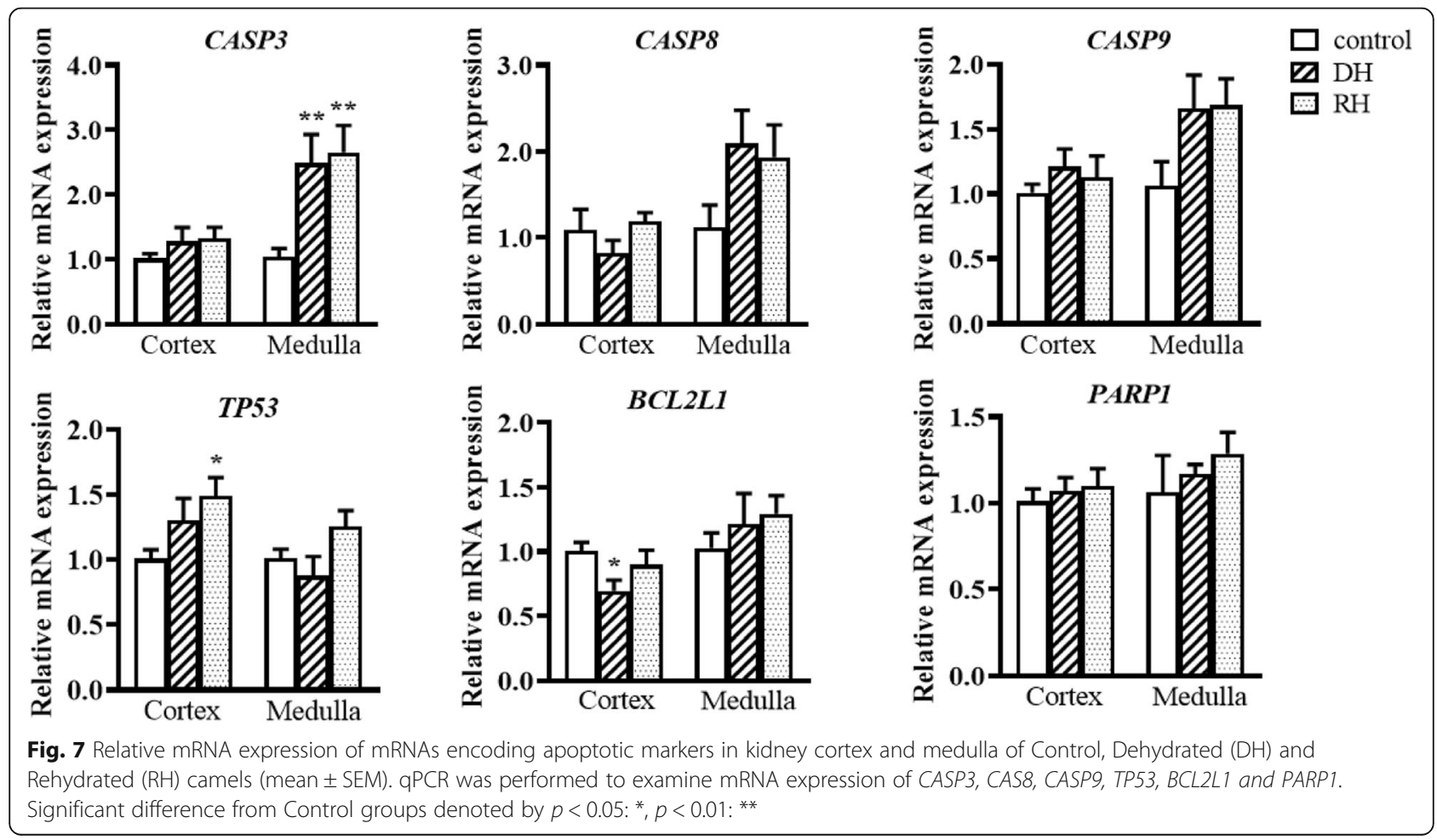


The discriminate rise of IL-18 in cortex and drop in medulla of dehydrated and rehydrated camels compared to controls might indicate that the kidney cortical cells independent of macrophage might be the source of IL18 productions similar to that observed in obstructive kidney injury [21]. The rise of IL-1 $\beta$ in kidney cortex of dehydrated camels is not surprising as it is involved in inflammation, apoptosis and other activities. In contrast to the cortex, IL-1 $\beta$ levels in medulla of dehydrated camels were not changed indicating little or no production of IL-1 $\beta$ at this site. No changes seen in IL- 6 protein levels in either cortex or medulla. Similarly, no changes observed in steady state IL-6 mRNA levels. However, there was no direct relationship between IL-1 $\beta$ and IL-18 protein abundance and the steady-state expression levels of the corresponding mRNAs. Indeed, whilst IL-18 protein increased because of dehydration in the cortex, the mRNA level decreased. Similarly, in the medulla, whilst dehydration caused IL-18 protein levels to go down, mRNA abundance went up.

ROS molecules (superoxides, peroxides, triple oxide radicals, oxidized thiol) are normally produced because of metabolic processes in the body. However, enzymatic (SOD, CAT) and non-enzymatic (GSH, free thiol, Vitamins $\mathrm{A}, \mathrm{C}$ and $\mathrm{E}$ ) antioxidants scavenge these to maintain a balanced redox status in the body $[54,6]$. On the other hand, disease conditions, chemicals toxins, strenuous exercise and dehydration can instigate over production of ROS, which rapidly proceed to form hydroxyl radical $(\mathrm{OH})$ and peroxynitrite oxidant $(\mathrm{ONO} 2)$ causing lipid peroxidation, proteins oxidation and DNA damage $[15,52]$. It is well known that the carbon-carbon double bond of polyunsaturated fatty acids are the target of lipid peroxidation by free radical and cytochrome oxidase with MDA and 4-HNE molecules as byproducts [7]. The high levels of the lipid oxidation marker, MDA, and antioxidant molecule GSH, and the depletion of SOD and CAT enzymes in the kidney cortex of dehydrated camels were clear signals of tissue oxidative stress. On the other hand, the kidney medulla seemed to be refractory to ROS as there was no changes in MDA, GSH, and SOD levels of dehydrated camels compared to controls. We also examined the steady-state levels of mRNAs that encode the enzymes responsible for MDA and GSH metabolism, and of the mRNAs that encode SOD and CAT. Interestingly, in addition to the increased levels of MDA in the cortex due to dehydration, we observed increased levels of PTGS1 mRNA, which is part of the pathway responsible for MDA synthesis. At the same time, we saw a decrease in the level of the mRNA encoding the MDA catabolic enzyme ALDH1L1. Similarly, levels of the GCLC mRNA, whilst not increased by dehydration in the cortex, were increased by rehydration, in parallel with the levels of GSH. Whilst CAT mRNA abundance did not change in the cortex as a consequence of dehydration, both SOD1 and SOD3 mRNA levels dropped, in parallel with SOD activity. Caspase enzymes, through intrinsic and extrinsic pathways [50, 59], induce apoptosis. The intrinsic pathway seems to be involved in the kidney cortex and medulla of dehydrated camels where caspases 9, 3 and p53 showed significant elevation. Normally, p53 concentration inside the cell is very low due to continuous turnover, but its level may become stabilized by stress to up-regulate various genes involved in apoptosis and other activities [40]. The intrinsic pathway of apoptosis seems to be dominant in the kidney of the dehydrated camel. The stress of long-term dehydration may induce DNA damage in cortical cells that will led to a significant elevation of $\mathrm{p} 53$ protein with activation of the pro-apoptotic factors, BAX and BAK via PUMA protein $[16,40]$. These pro-apoptotic proteins lead to mitophagy, and promote mitochondrial membranes to release cytochrome c, apoptosis inducing factor (AIF). These, in turn, form complexes in the cytosol and activate caspase 9 and hence caspase 3, leading, ultimately, to cell execution $[10,40]$. BCL-xl is an anti-apoptotic protein, encoded by the $B C L 2 L 1$ gene [11]. Its main function is to protect the mitochondrial membranes from pro-apoptotic proteins to form pores and facilitate the release of cytochrome c $[18,40]$. BCL-xl also functions in the regulation of ATP synthesis, autophagy and cell mitosis [38]. There was a significant decrease of BCL-xl concentration in both kidney cortex and medulla of dehydrated camels, suggesting that apoptosis might be activated $[20,38]$. PARP1 is usually engaged in DNA repair however, the enzyme remains active even if damage could not be amended, a process that leads to $\mathrm{NAD}^{+}$depletion and ATP overconsumption to escalate a cell energy crisis [3, 39]. This leads to collapse of mitochondrial membrane potential, passage of apoptotic inducing factor, fragmentation of DNA and condensation of chromatin material [17, 29]. We report increased PARP activity in both cortex and medulla of dehydrated camels with a further elevation of PARP1 activity in the cortex 72-h post rehydration. However, it is not clear whether the rise of PARP1 plays a potential role in the programed cell death reported in the kidney of the dehydrated camels. It is worth mentioning that PARP1 activity in the medulla returned to normal along with ATP synthase activity, which might point to $\mathrm{NAD}^{+} / \mathrm{ATP}$ restoration early in that part of kidney. Supporting data for this notion will be published in another manuscript.

Quantification of steady-state mRNA levels suggested that the activation of apoptosis might be regulated, at least in part, at this level. Thus, CASP3 mRNA levels are induced by dehydration in the medulla in parallel with the protein, whereas $B C L 2 L 1$ mRNA levels decrease in 
the cortex, along with the corresponding BCL-xL protein.

We were interested to ask whether alterations in steady-state mRNA levels were responsible for the inflammatory, oxidative stress and apoptotic changes observed as a consequence of dehydration and rehydration. Some direct correlations were observed, but in the main, our results suggest that, under these stressful conditions, there is no necessary direct relationship between steadystate mRNA levels and the abundance or activity of the corresponding protein. In these cases, regulation is presumably being effected downstream of steady-state mRNA level, perhaps, for different proteins, at different levels; for example, translation rate, protein compartmentalization, transport, translocation, secretion, post-translational modification, protein stability and activity-dependent turnover [33].

\section{Some limitations of our study deserve mention}

Although we standardized the samples as much as possible, some variation is inevitable with the use nonmodel organisms such as the dromedary camel. We would have preferred direct measurements of body weight over derived values based on a number of length measurements each with their own potential for error. Despite best efforts to minimize the time between slaughter and tissue harvesting, some samples were exposed longer at ambient temperature before freezing, potentially affecting their quality. Further, the samples were kept frozen for a number of years at $-80 \mathrm{C}$ to maintain integrity, but some degradation might have occurred. We noted differences in age and weight of our camels, with some animals being older and heavier than others, which could affect the response to dehydration. Physical differences were also observed, with animals differing in coat colours, for example. Crossbreeding to give rise to animals with specific characteristics is a common practice in the region, and colour is often used to monitor this. This could result in genetic variations in the kidney. Studies based on non-model species are expected to exhibit considerable biological variation, which engenders uncertainty with regards to physiological and genetic measurements regardless of the technology applied. These challenges should be understood as an unavoidable limitation of doing research with non-model species. Nonetheless, we are confident that the variability shown in these experiments is a consequence of biological differences rather than technical bias.

\section{Conclusions}

Long-term dehydration and subsequent rehydration provoke profound changes in the kidney. We have documented increases in pro-inflammatory cytokines, oxidative stress and apoptosis. In addition to some gene expression that support these changes. However, kidney cortex and medulla often differ in their responses to dehydration and short-term rehydration.

\section{Methods \\ Chemicals, kits and antibodies}

Sodium deoxycholate, total Glutathione (GSH) enzyme kinetic assay kit, 3,3',5,5' -Tetramethylbenzidine (TMB), and all other chemicals, if not specified were purchased from Sigma-Aldrich Chemical Company (Sigma Chemical Co., St. Louis, MO, USA). Complete protease inhibitor cocktail was purchased from Thermo Fisher Scientific Inc. (MA USA, 02,451). Catalase (CAT), Superoxide dismutase (SOD), assay kits were purchased from (Cayman Chemical Company, Ann Arbor, MI, USA). Bcl-xL, p53 ELISA kits were purchased from R\&D Systems (MN, USA). Assay kits for camel ELISA and for IL-1 $\beta$, IL-6, IL-18, TNF- $\alpha$, Caspase 8, 9, PARP1, were purchased from MyBiosource, Inc. (CA 92,195-3308, USA). Caspase 3 assay kits were purchased from Promega Corporation (Madison, WI 53,711, USA). Malondialdehyde (MDA) Assay kits were purchased from Northwest Life Science Specialties, (WA, USA).

\section{Animals}

Nineteen healthy male one-humped camels, 4-5 years old with body weight range of $276-416 \mathrm{~kg}$, were used for this study. Animals were purchased from a local camel trading company (ALBWADRY CAMEL TRAD ING COMPANY). After a short adjustment period, the camels were divided randomly into three groups; Control group $(n=5)$, Dehydrated group $(n=8)$, and rehydrated group $(n=6)$. The camels were visited daily by an experienced Veterinarian to ensure their wellbeing. The control group were supplied with feed and water ad libitum for the whole experimental period. The dehydrated group were provided with feed ad libitum but without water for 20 days, while the rehydrated group was provided with feed ad libitum, restricted of water for 20 days and thereafter allowed free access to water for $72 \mathrm{~h}$. The animals were kept in a shaded corral during the months of (April and May, $40-50{ }^{\circ} \mathrm{C}$ ) in the Eastern Region of the United Arab Emirates. The camels were maintained on alfalfa green grass and dry hay. At the end of the experimental period, camels were sacrificed in the central abattoir for human consumption. Camel kidney samples were collected from all camels.

\section{Preparation of kidney homogenate}

Kidney homogenate was prepared as described earlier [6]. Briefly, kidney tissue was washed with ice-cold phosphate buffer saline (PBS), cortex and medulla were separated. Tissue was weighed and homogenized with complete protease inhibitor cocktail. The resulting 
Table 3 Primers for qPCR

\begin{tabular}{|c|c|c|c|c|}
\hline Gene & Corresponding protein & $\begin{array}{l}\text { NCBI reference } \\
\text { sequence (mRNA) }\end{array}$ & $\begin{array}{l}\text { 5' to 3' primer sequence } \\
\text { (F: forward, R: reverse) }\end{array}$ & $\begin{array}{l}\text { Product } \\
\text { size }(b p)\end{array}$ \\
\hline PPIA & Peptidylprolyl isomerase A & XM_010987886.1 & $\begin{array}{l}\text { F: ACCACCAGACCATTCCTTCT } \\
\text { R: TATGGAACCCCGAAAACTGC }\end{array}$ & 109 \\
\hline CAT & Catalase & XM_011000575.1 & $\begin{array}{l}\text { F: AGACTTGCCCAGGAAGATCC } \\
\text { R: GTCCAGGAGGGATAGTTGCC }\end{array}$ & 80 \\
\hline SOD1 & Superoxide dismutase 1 & XM_010977357.1 & $\begin{array}{l}\text { F: ACCATCCACTTCGAGCAGAA } \\
\text { R: ATGGACCCCGATACCATGAC }\end{array}$ & 86 \\
\hline SOD2 & Superoxide dismutase 2 & NM_001319878.1 & $\begin{array}{l}\text { F: TACTGGAAGCCATCAACCGT } \\
\text { R: GCAATCTGTAAGCGTCCCTG }\end{array}$ & 136 \\
\hline SOD3 & Superoxide dismutase 3 & XM_010991051.1 & $\begin{array}{l}\text { F: CTCTGTGCCTACCTGCTCAT } \\
\text { R: TGCCAGATCTCCGTCACTIT }\end{array}$ & 128 \\
\hline GCLC & $\begin{array}{l}\text { Glutamate- cysteine ligase } \\
\text { catalytic subunit }\end{array}$ & XM_010992378.1 & $\begin{array}{l}\text { F: ACCAGAGTACGGGAGCTACA } \\
\text { R: GTCCTCCACGGTGTTGAACT }\end{array}$ & 85 \\
\hline GSS & Glutathione synthetase & XM_010975159.1 & $\begin{array}{l}\text { F: AGCTATGCCCCATTCACACT } \\
\text { R: ACCAGCAGGTTGAAGTCCAT }\end{array}$ & 92 \\
\hline TBXAS1 & Thromboxane A synthase 1 & XM_010983188.1 & $\begin{array}{l}\text { F: GCCCTGTTAGTGGTCCTCTT } \\
\text { R: GGAGAAGGCTTGGGATGTCT }\end{array}$ & 98 \\
\hline PTGS1 & $\begin{array}{l}\text { Prostaglandin- endoperoxide } \\
\text { synthase } 1\end{array}$ & XM_010997991.1 & $\begin{array}{l}\text { F: CGTGGAGTTCAACCAGCTCTA } \\
\text { R: AGGTGTTGAAGAGGAACTGCT }\end{array}$ & 101 \\
\hline PTGS2 & $\begin{array}{l}\text { Prostaglandin- endoperoxide } \\
\text { synthase } 2\end{array}$ & XM_010992100.1 & $\begin{array}{l}\text { F: CTGGTCTGATGATGTACGCC } \\
\text { R: ACAACCGCTCATCATCCCAT }\end{array}$ & 99 \\
\hline ALDH1L1 & $\begin{array}{l}\text { Aldehyde dehydrogenase } 1 \\
\text { family member } \\
\text { L1 }\end{array}$ & XM_010998232.1 & $\begin{array}{l}\text { F: GTCCAGGGGTAGTCACCAAA } \\
\text { R: CGTTCTTCACCAGCAGCATT }\end{array}$ & 72 \\
\hline ALDH1A1 & $\begin{array}{l}\text { Aldehyde dehydrogenase } 1 \\
\text { family member } \\
\text { A1 }\end{array}$ & XM_010999961.1 & $\begin{array}{l}\text { F: TCCTITGGAAGATAGCGCCT } \\
\text { R: GTCCGTAGCCTGGGACAATA }\end{array}$ & 153 \\
\hline \multirow[t]{2}{*}{ ACSS1 } & Acyl-CoA synthetase short & XM_010992742.1 & $\begin{array}{l}\text { F: GAGCTGAAGAGGATCGTGGAT } \\
\text { R: TGCTCGAGGGGTATGTCCA }\end{array}$ & 119 \\
\hline & chain family member 1 & & & \\
\hline ACSS2 & $\begin{array}{l}\text { Acyl-CoA synthetase short } \\
\text { chain family member } 2\end{array}$ & XM_010975158.1 & $\begin{array}{l}\text { F: ACAGTTGGAGGCTACATGCT } \\
\text { R: TGCACCAGAACACATCCTCT }\end{array}$ & 82 \\
\hline GPI & Glucose-6-phosphate isomerase & XM_010989123.1 & $\begin{array}{l}\text { F: TGCCATTITCTGCAGCTTGA } \\
\text { R: ATCACAGCCTCCGTCACAA }\end{array}$ & 88 \\
\hline$I L-1 B$ & Interleukin 1 beta & XM_010984994.1 & $\begin{array}{l}\text { F: TGAACCCGCCAGTGAAATGA } \\
\text { R: GACGCAGCACTTCATCTGTT }\end{array}$ & 94 \\
\hline $\mathbb{L L}-6$ & Interleukin 6 & XM_010987177.1 & $\begin{array}{l}\text { F: GGTACCCCTGGGAGAAGATT } \\
\text { R: GCAGAGATTCTGCCGAGGAT }\end{array}$ & 108 \\
\hline $\operatorname{LL}-18$ & Interleukin 18 & XM_010986146.1 & $\begin{array}{l}\text { F: AGGTGTGGCAGTAACCATCT } \\
\text { R: TCAGGAGGGCTCATTTCCTT }\end{array}$ & 96 \\
\hline CASP3 & Caspase 3 & XM_010974562.1 & $\begin{array}{l}\text { F: GCTTCTTCAGAGGGGACAGT } \\
\text { R: TCGGCAGGCCTGAATAATGA }\end{array}$ & 71 \\
\hline CASP8 & Caspase 8 & XM_010991975.1 & $\begin{array}{l}\text { F: TGAAAGCAGTCCAGGGGAAA } \\
\text { R: ATGTCTCTGGCTCACTGTCC }\end{array}$ & 119 \\
\hline CASP9 & Caspase 9 & XM_011000878.1 & $\begin{array}{l}\text { F: CGGACGCCATGTCTAGTTTG } \\
\text { R: TCCCTCCAGGAGACAAAACC }\end{array}$ & 82 \\
\hline TP53 & Tumor protein p53 & XM_010996514.1 & $\begin{array}{l}\text { F: GCCCCTCCTCAGCATCTTAT } \\
\text { R: CCACCACACTGTGTCGAAAA }\end{array}$ & 88 \\
\hline$B C L 2 L 1$ & B-cell lymphoma-extra large & XM_010993888.1 & $\begin{array}{l}\text { F: GTITGAACTGAGGTACCGGC } \\
\text { R: CCCATCCCGGAAGAGTTCAT }\end{array}$ & 115 \\
\hline PARP1 & Poly ADP-ribose polymerase 1 & XM_010992461.1 & $\begin{array}{l}\text { F: TGCATGGTCAAGACCCAGAT } \\
\text { R: GGGAATATACGGTCCTGCCT }\end{array}$ & 113 \\
\hline
\end{tabular}


homogenates were centrifuged and the supernatant stored at $-80{ }^{\circ} \mathrm{C}$ until assayed.

\section{Measurement of pro-inflammatory cytokines}

Camel ELISA kits (MyBiosource) were used to measure levels of IL-1 $\beta$, IL- 6 and IL-18 in kidney homogenate as per the manufacturer's protocol. Briefly, sample and standards were added to the coated 96 well micro titer plate for $1 \mathrm{~h}$ at $37{ }^{\circ} \mathrm{C}$. The absorbance was read at $450 \mathrm{~nm}$, and expressed as $\mathrm{pg} / \mathrm{mg}$ tissue [6].

\section{Estimation of oxidative stress biomarkers (GSH, CAT, SOD, and MDA)}

Levels in kidney homogenate measured according to manufacturer's protocol using commercially available kits [6]. Briefly, using a kinetic assay, GSH was reduced to glutathione disulfide (GSSG) and the product measured spectrophotometrically. For CAT assay the method was based on reaction of the enzyme with methanol in the presence hydrogen peroxide $(\mathrm{H} 2 \mathrm{O} 2)$ and $\mathrm{d}$ the product was measured spectrophotometrically. For SOD assay, we utilized the tetrazolium salt for the detection of superoxide radicals generated by xanthine oxidase and hypoxanthine. For MDA assay, we used the reaction of MDA with thiobarbituric acid (TBA) to form a MDA-TBA adduct that was absorbed strongly at $532 \mathrm{~nm}[6]$.

\section{Measurement of apoptotic markers}

ELISAs and assays for caspases 3, 8, 9, BCL-xL, p53 and PARP1 were performed according to the manufacturer's protocol as described earlier [6]. The absorbance was read with an Emax Plus microplate reader (Molecular devices, CA 94,089, USA). Results were expressed as ng/ mg tissue.

\section{RNA extraction and CDNA synthesis}

Frozen renal cortex and medulla were separated using sterile scalpel and a surgical saw. Tissue samples were crushed to a fine powder under liquid nitrogen with a mortar and a pestle. Powdered tissue was placed into $1.5 \mathrm{~mL}$ RNAse free tubes maintained on dry ice. Total RNA was extracted from approximately $30 \mathrm{mg}$ of powdered tissue using a Direct-zol ${ }^{\text {Tx }}$ RNA MiniPrep kit (Zymo research; R2052) following the manufacturer's instructions. For cDNA synthesis, $1000 \mathrm{ng}$ of RNA from each sample was reversely transcribed using the GOScriptTM cDNA synthesis system (Promega; A276A).

\section{Real-time quantitative PCR analysis}

Primers Table 3 were designed based on National Center for Biotechnology Information (NCBI) reference sequences (RefSeq) for target genes and were synthesized by Sigma-Aldrich ${ }^{\circ}$. The optimization and validation of primers were performed according to normal ABI protocols and the relative standard curve method [45]. The cDNA samples from reverse transcription were used as templates for the qPCR which was conducted in duplicates in $10 \mu \mathrm{l}$ reaction volumes using Power UpTM SYBR Green Master Mix (Thermo Fisher Scientific,100, 029,283) on an ABI StepOne-Plus Real-Time PCR System. The reference gene PPIA was used as the internal control gene for qPCR on the basis of its stability and robust CT value [24]. $2^{-\Delta \Delta C T}$ method was applied for the relative quantification of gene expression [32]. Studies were performed in accord with MIQE guidelines [14].

\section{Statistical Analysis}

Statistical analyses were performed by independent t-test using SPSS (Statistical Package for Social Sciences, version 23: SPSS, Chicago, USA) or Graphpad Prism 8 software. Data shown as mean \pm SEM and $p$ value less than 0.05 defined statistically significant.

\section{Abbreviations}

BCL-xl: B-cell lymphoma-extra-large i CAT: Catalase; DNA: Deoxyribonucleic acid; ELISA: Enzyme-linked immunosorbent assay; GSH: Total Glutathione; IL1B: Interleukin 13; IL-6: Interleukin 6; IL-18: Interleukin 18;

MDA: Malondialdehyde; mRNA: Messenger Ribonucleic Acid; NCB1: National Center for Biotechnology Information; PARP1: Poly ADP-ribose Polymerase; p53: Tumor protein 53; qPCR: Quantitative Polymerase Chain Reaction; RNA: Ribonucleic acid; ROS: Reactive oxygen species; SOD: Superoxide dismutase; TNF-a: Tumor Necrosis Factor a; SOD1, 2, 3: Superoxide dismutase

1, 2, 3 genes; TBXAS1: Thromboxane A synthase 1; PTGS1 and

PTGS2: Prostaglandin-endoperoxide synthase 1 and 2; ALDH1L1: Formyl tetrahydrofolate dehydrogenase-10; ALDH1A1: Aldehyde Dehydrogenase 1 Family Member A1; ACSS1: Acyl-CoA Synthetase Short Chain Family Member 1; ACSS2: Acyl-CoA Synthetase Short Chain Family Member 2; GPI: Genuine progress indicator; GCLC: Glutamate-Cysteine Ligase Catalytic Subunit; GSS: Glutathione synthetase (GSH synthesis); CASP3: Caspase 3; CASP8: Caspase 8; CASP9: Caspase 9; TP53: Tumor protein 53; BCL2L1: Is a human gene, it encodes both of the human proteins $\mathrm{BCl}-\mathrm{xL}$ and $\mathrm{BCl}-\mathrm{xS}$

\section{Acknowledgement}

We fully acknowledge the support of UAEU and Leverhulme Trust for their generous grants.

\section{Authors' contributions}

Conceived and designed the experiments: MAA, DM \&AA. Performed the experiments: NA, OMA, ST, MPG, PL, BG. Analyzed the data: MAA, HAD, NA, OMA, ST, AA, DM. Wrote the paper: MAA, HAD, AA, DM. Revised the paper: NA, OMA, ST, MPG, PL, BG, DM \& AA. All authors read and approved the final manuscript.

\section{Funding}

This study supported by two grants: Prof. Abdu Adem grant from the United Arab Emirates University (UAEU)-Program for Advanced Research (UPAR31M242). Prof. David Murphy grant was from the Leverhulme Trust (RPG2017-287). The funders had no role in study design, data collection and analysis, decision to publish, or preparation of the manuscript.

Availability of data and materials

The datasets used and/or analysed during the current study are available from the corresponding author on reasonable request.

Ethics approval and consent to participate

The Animal Ethics Committee of the United Arab Emirates University approved the study protocol (approval ID No ERA-2016-4327): During the 
experimental period, all applicable international, national, and/or institutional guidelines for the care and use of animals was followed. Animals purchased from a local camel trading company called AL BWADRY CAMEL TRADING COMPANY.

\section{Consent for publication}

Not applicable.

\section{Competing interests}

The authors declare that they have no competing interests.

\section{Author details}

'Department of Pharmacology, CollegeofMedicine\&HealthSciences, United Arab Emirates University, Al- Ain, United Arab Emirates. ${ }^{2}$ College of Medicine and Public Health, Flinders University, Adelaide, Australia. ${ }^{3}$ Department of Anatomy, CollegeofMedicine\&HealthSciences, Emirates University, Al-Ain, United Arab Emirates. ${ }^{4}$ Molecular Neuroendocrinology Research Group, Bristol Medical School, Translational Health Sciences, University of Bristol, Dorothy Hodgkin Building, Bristol BS13NY, UK. ${ }^{5}$ Department of Pharmacology, College of Medicine and Health Sciences, Khalifa University, P.O.Box 127788, Abu Dhabi, UAE.

\section{Received: 13 February 2020 Accepted: 19 October 2020} Published online: 23 November 2020

\section{References}

1. Abdalla MA, Abdalla O. Morphometric observations on the kidney of the camel. Camelus dromedaries J Anat. 1979;129(1):45-50.

2. Adem A, Haj MA, Sheela B, Pathan JY, et al. ANP and BNP responses to dehydration in the one-humped camel and effects of blocking reninangiotensin system. PLoS ONE. 2013;8(3):e57806.

3. Alano CC, Ying W, Swanson RA. Poly (ADP-ribose) polymerase-1-mediated cell death inastrocytes requires NAD+ depletion and mitochondrial permeability transition. J Biol Chem. 2004;279(18):18895-902 (PubMed: 14960594).

4. AlHaj M, Kazzam E, Nagelkerke NJ, Nyberg F, Nicholls MG, Adem A. Effect of dehydration in the presence and absence of the Angiotensin receptor blocker Losartan on blood constituents in the camel. Journal of Medical Sciences. 2011;4:1-6.

5. Ali MA, Kazzam E, Naheed Amir, Nyberg F, Adem A, 2013 Effects of dehydration and blockade of Angiotensin 11 AT1 receptor on stress hormones and anti-oxidants in the one-humped camel BMC Veterinary Research 9232 http://www.biomedcentral.com/1746-6148/9/232.

6. Ali MA, Abu Damir H, Amir N, Adeghate EA, Bastaki S, Murphy D, Adem A. Effects of long-term dehydration on oxidative stress, apoptotic markers and neuropeptides in the gastric mucosa of the dromedary camel. Mol Cell Biochem. 2018. https://doi.org/10.1007/s11010-018-3474-x.

7. Ayala A, Muñoz MF, Argüelles S. "Lipid Peroxidation: Production, Metabolism, and Signaling Mechanisms of Malondialdehyde and 4-Hydroxy2-Nonenal,". Oxidative Medicine and Cellular Longevity. 2014;2014(360438):31.

8. Beniwal G, Singh K, Joshi S. Histomorphological study of juxtaglomerular apparatus, macula densa, Becher's cells, polkissen cells and stellate veins of kidney in camel, (Camelus dromedarius). Indian Veterinary Medical Journal. 1997;21(1):23-5.

9. Beniwal G, Singh K, Joshi S. Microscopic study of uriniferous tubules and collecting ducts of kidney in camel (Camelus dromedarius). Journal of Camel Practice and Research. 1998:5(1):107-9.

10. Bensaad K, Vousden KH. p53: new roles in metabolism. Trends Cell Biol. 2007;17:286-91.

11. Boise LH, Gonzalez-Garcia M, Postema CE, et al. BCl-x, A BCl-2-related gene that functions as a dominant regulator of apoptotic cell death. Cell. 1993; 74(4):597-608.

12. Bouby N, Fernandes S. Mild dehydration, vasopressin and the kidney: animal and human studies. Eur J Clin Nutr. 2003;57(Suppl 2):S39-46.

13. Burg MB, Ferraris JD, Dmitrieva NI. Cellular response to hyperosmotic stresses. Physiol Rev. 2007;87(4):1441-74.

14. Bustin SA, Benes V, Garson JA, Hellemans J, Huggett J, Kubista M, Mueller R, Nolan T, Pfaffl MW, Shipley GL, Vandesompele J, Wittwer CT. The MIQE guidelines: minimum information for publication of quantitative real-time PCR experiments. Clin Chem. 2009;55:611-22.
15. Cadenas E, Mechanisms of oxygen activation and reactive oxygen species detoxification, in Oxidative stress and antioxidant defenses in biology. 1995, Springer. p. 1-61.

16. Chipuk JE, Bouchier-Hayes L, Kuwana T, Newmeyer DD, Green DR. Cell biology: PUMA couples the nuclear and cytoplasmic proapoptotic function of p53. Science. 2005;309(5741):1732-5.

17. Cipriani G, Rapizzi E, Vannacci A, Rizzuto R, Moroni F, Chiarugi A. Nuclear poly(ADP-ribose) polymerase-1 rapidly triggers mitochondrial dysfunction. J Biol Chem. 2005;280(17):17227-34.

18. Dejean LM, et al. Regulation of the mitochondrial apoptosis-induced channel, MAC, by BCL 2 family proteins. Biochim Biophys Acta. 2006;1762(2): 191-201 ([PubMed: 15750180]).

19. Eissa L, Ali HA, Ismail HI. Histological and ultrastructural study on theJuxtaglomerular apparatus in the kidney of the dromedary camel (camelus dromedaries). Int J Curr Adv Res. 2017:6:6776-83.

20. Finucane DM, Bossy-Wetzel E, Waterhouse NJ, Cotter TG, Green DR. Baxinduced Caspase Activation and Apoptosis via Cytochrome c Release from Mitochondria Is Inhabitable by Bcl-xL. The Journal of Biological Chemistry. 1999;274:2225-33. https://doi.org/10.1074/jbc.274.4.2225.

21. Franke El, Vanderbrink BA, Hile KL, Zhang H, Cain A, et al. Renal IL-18 Production Is Macrophage Independent During Obstructive Injury. PLoS ONE. 2012;7(10):e47417. https://doi.org/10.1371/journal.pone.0047417.

22. Gebreyohanes MG, Assen AM. Adaptation Mechanisms of Camels (Camelus dromedarius) for Desert Environment A Review. J Vet Sci Technol. 2017;8:6. https://doi.org/10.4172/2157-7579.1000486.

23. Ghayur T, Banerjee S, Hugunin M, Butler D, Herzog L, et al. Caspase-1 processes IFN-gamma- inducing factor and regulates LPS-induced IFNgamma production. Nature. 1997;386:619-23.

24. Gholami K, Loh SY, Salleh N, Lam SK, Hoe SZ. Selection of suitable endogenous reference genes for qPCR in kidney and hypothalamus of rats under testosterone influence. PLoS ONE. 2017;12(6):e0176368.

25. Hermes-Lima, M., J.M. Storey, and K.B. Storey, Antioxidant defenses and animal adaptation to oxygen availability during environmental stress, in Cell and Molecular Response to Stress. 2001, Elsevier. p. 263-287.

26. Hilliard LM, Mirabito Colafella KM, Bulmer LL, Puelles VG, Singh RR, Ow CPC, Gaspari T, Drummond GR, Evans RG, Vinh A, Denton KM. Chronic recurrent dehydration associated with periodic water intake exacerbates hypertension and promotes renal damage in male spontaneously hypertensive rats Scientific Reports. 2016;6:33855. https://doi.org/10.1038/srep33655.

27. Lee Jae-Kwon Kim Soo-Hyun Eli C Lewis Tania Azam Leonid L Reznikov Charles A Dinarello Differences in signaling pathways by IL-1 $\beta$ and IL-18. PNAS June 8, 200420041012388158820.

28. Jaisser F, Farman N. Emerging Roles of the Mineralocorticoid Receptor in Pathology. Pharmacol Rev. 2016;68:49-75. https://doi.org/10.1124/pr.115.011106.

29. Kiraz Y, Adan A, Kartal Yandim M, Baran Y. Major apoptotic mechanisms and genesinvolved in apoptosis. Tumor Biol. 2016;37:8471-86. https://doi.org/10. 1007/s13277-016-5035-9.

30. Kohler-Rollefson I, Mundy P. Mathias I. Virginia: A Field Manual of Camel Diseases; 2001.

31. Kumar A and Tyagi MG. Hypertonicity induced modulation of gene transcription and translation of water regulatory molecules. Biomed Res. 2011;22(1):93-101.

32. Livak KJ, Schmittgen TD. Analysis of relative gene expression data using real-time quantitative PCR and the 2 (delta C (T)) method. Methods. 2001; 25:402-8.

33. Liu Y, Beyer A, Aebersold R. On the Dependency of Cellular Protein Levels on mRNA Abundance. Cell. 2016;165(3):535-50.

34. Liu Z, Wang H, Xiao W, Wang C, Liu G, Hong T. Thyrocyte interleukin-18 expression is up regulated by interferon-c and may contribute to thyroid destruction in Hashimoto's thyroiditis. Int J Exp Path. 2010;91:420-5.

35. MacManes M. Severe acute dehydration in a desert rodent elicits a transcriptional response that effectively prevents kidney injury. BioRxiv 2017 10.1101/103077.

36. Marieb Elaine Nicpon, Hoehn Katja "Chapter 16" Human anatomy \& physiology 9 Boston Pearson 2013629 Question 14. OCLC 777127809.

37. Mbassa GK. Mammalian renal modifications in dry environments. Vet Res Commun. 1988;12(1):1-18.

38. Michels J, Kepp O, Senovilla L, Lissa D, Castedo M, Kroemer G, Galluzzi L 2013 Functions of BCL-XL at the Interface between Cell Death and Metabolism International Journal of Cell Biology 2013 doi.org/10.1155/2013/ 705294. 
39. Morales JC, Li L, Fattah FJ, Dong Y, Bey EA, Patel M, Gao J, Boothman DA. Review of Poly (ADP-ribose) Polymerase (PARP) Mechanisms of Action and Rationale for Targeting in Cancer and Other Diseases. Crit Rev Eukaryot Gene Expr. 2014;24:15-28.

40. Olivier M, Petitjean A, Marcel V, Petre A, Mounawar M, Plymoth A, de Fromentel CC. Hainaut P (2009) Review: Recent advances in p53 research: an interdisciplinary perspective. Cancer Gene Ther. 2009;16:1-12.

41. Paik IY, Jeong MH, Jin HE, Kim YI, Suh AR, Cho SY, Roh HT, Jin CH, Fluid Suh $\mathrm{SH}$. replacement following dehydration reduces oxidative stress during recovery. Biochem Biophys Res Comm. 2009;22:103-7.

42. Parikh CR, Jani A, Melnikov VY, Faubel S, Edelstein CL. Urinary interleukin-18 is a marker ofhuman acute tubular necrosis. Am J Kidney Dis. 2004;43:40514 ([PubMed]).

43. Parikh et al. Urine IL-18 is an early diagnostic markerfor acute kidney injury and predicts mortality in the intensive care unit. J Am Soc Nephrol. 2005;16: 3046-52.

44. Peraza S, Wesseling C, Aragon A, et al. Decreased kidney function among agricultural workers in El Salvador. Am J Kidney Dis. 2012;59:531-40.

45. Pfaffl MW. Quantification strategies in real-time PCR. The Real-Time PCR Encyclopedia A-Z of quantitative Safer, A.M., and Abo-Salem, K.S., (1991): Ultrastructure of the nephron of the young camel (Camelus dromedarius). J Morphol. 2004:210:101-15.

46. Prasad M, Walker AN, Kaur J, Thomas JL, Powell SA, Pandey AV, Whittal RM, Burak WE, Petruzzelli G, Bose HS. Endoplasmic reticulum stress enhances mitochondrial metabolic activity in mammalian adrenals and gonads. Mol Cell Biol. 2016:36:3058-74. https://doi.org/10.1128/MCB.00411-16.

47. Safer AM, Abo-Salem KS. Ultrastructure of the nephron of the young camel (Camelus dromedarius). J Morphol. 1991;210:101-15.

48. Schoorlemmer GHM, Evered MD. Reduced feeding during water deprivation depends on hydration of the gut. Am J Physiol Regulatory Integr Comp Physiology. 2002;283(5):R1061-9.

49. Schroter RC, Robertshaw D, Baker MA, Shoemaker VH, Holmes R, SchmidtNielsen K. Respiration in heat stressed camels. Respir Physiol. 1987;70:97-112.

50. Shen Y, White E. p53-dependent apoptosis pathways. Adv Cancer Res. 2001; 82:55-84.

51. Shui HA, Ka SM, Wu WM, Lin YF, Hou YC, Su LC, Chen A. LPS-evoked IL-18 expressionin mesangial cells plays a role in accelerating lupus nephritis. Rheumatology (Oxford). 2007;46:1277-84 ([PubMed]).

52. Stagos D, Goutzourelas N, Bar-Or D, Amalia-Maria N, Bella E, Becker AT, Statiri A, Kafantaris I, Kouretas D. Application of a new oxidation-reduction potential assessment method in strenuous exercise-induced oxidative stress. Redox Rep. 2015;20(4):154-62. https://doi.org/10.1179/1351000214Y. 0000000118.

53. Sutinen EM, Pirttilä T, Anderson G, Salminen A, Ojala JO. Pro-inflammatory interleukin-18 increases Alzheimer's disease-associated amyloid- $\beta$ production in human neuron-like cells. J Neuroinflammation. 2012;9:199.

54. Valko M, Leibfritz D, Moncol J, Cronin MTD, Mazur M, Telser J. Free radicals and antioxidants in normal physiological functions and human disease. Int J Biochem Cell B. 2007;39:44-84.

55. Verlander JW. Normal Ultrastructure of the Kidney and Lower Urinary Tract. Toxicol Pathol. 1998;26:1-17.

56. Wijkstrom J, Leiva R, Elinder CG, et al. Clinical and pathological characterization of Mesoamerican nephropathy: a new kidney disease in Central America. Am J Kidney Dis. 2013;62:908-18.

57. Wu et al. IL-18 contributes to renal damage after ischemia-reperfusion Journal of the American Society of Nephrology: JASN. 2008;19(12):2331-41.

58. Wyburn K, Wu H, Yin J, Jose M, Eris J, Chadban S. Macrophage-derived interleukin-18in experimental renal allograft rejection. Nephrol Dial Transplant. 2005;20:699-706 ([PubMed])

59. Yuan J, Najafov A, Py BF. Roles of Caspases in Necrotic Cell Death. Cell. 2016;167(7):1693-704.

\section{Publisher's Note}

Springer Nature remains neutral with regard to jurisdictional claims in published maps and institutional affiliations.

\section{Ready to submit your research? Choose BMC and benefit from:}

- fast, convenient online submission

- thorough peer review by experienced researchers in your field

- rapid publication on acceptance

- support for research data, including large and complex data types

- gold Open Access which fosters wider collaboration and increased citations

- maximum visibility for your research: over $100 \mathrm{M}$ website views per year

At BMC, research is always in progress.

Learn more biomedcentral.com/submissions 